\title{
BIRDBATHS IN WINTER
}

\section{Cecelia L. Hill, Nanaimo, Vancouver Island}

$\mathbf{W}^{1}$ ITH the advent of winter the birds who have ignored the feeding table for the rest of the year now become regular and frequent visitors. First come the Juncos who rarely visit at all in the summer; the Winter Wrens who remain all the year round; the Spotted Towhees, usually so very retiring in their habits; the Robins, perhaps for a change of diet; the Song Sparrows, large and smail, and the Varied Thrushes, who leave us for the woods in the spring. The odd Chickadee comes to the garden rarely, presumably because sufficient food more to their liking can be found elsewhere.

The bird table is roofed with the south and east sides completely enclosed to exclude the prevailing winds and rain. It is under a rustic archway over which in the summer wisteria climbs. The arch and creeper protect the birds from hawks, also hide the food from Crows and Seagulls who hover overhead when activity by the smaller birds attracts them with their voracious appetites.

The two bird baths, the one somewhat covered by the wisteria arch and the other by a hemlock from the next door garden, are fairly secluded from the hawks who, given a clear sweep, will dive down on the small birds with disastrous results and even when they are feeding close to the house.

The bird batths are a constant source of interest. Some birds dance

round the sides taking fluttering jumps into the water and out again - like jittery bathers at the beachbefore settling down to a real splash. Sometimes I think they appreciate the water warmed and hope when I do that none who indulge suffer ill effects. I never attempted winter bird baths on the prairie, but out here have the birds bathing all the year round even when snow covers the sides of the bird bath.

I have often wondered if there is any data regarding whether birds bathe prior to rain. It has always seemed to me they do, particularly on the prairie during the summer months, when before rain they seemed to line up in considerable numbers. Here in the winter months it seems to me we always get rain or snow after they indulge. Just why a bird should bathe before rain it seems hard to understand unless it increases the secretion of oil in some way to protect the feathers from the rain. A saturated bird is a pitiable sight.

Now whether all our winter visitors are the same birds who reside with us during the summer I am not prepared to say, they may be migrants from farther north who winter with us while our summer birds go further south. I have seen all the species mentioned here or elsewhere on Vancouver Island all the year around except the larger Song Sparrows. Those I have only seen so far during the winter months.

\section{Fours of Enjoyment}

Mrs. W. Hannam, Verdun, Que.

WE spend our summers on an island in the St. Lawrence River at the foot of the Lachine Rapids. Some nine years ago this island was made a bird sanctuary, and the increase in bird life is amazing. We are entirely cut off from city life-there being no roads, consequently no cars, no electricity or movies. All pleasure is self made.

We spend many hours watching birds and coaxing them to stay around our house. By the time the summer is over some of them are quite tame. At feeding time they will fly over to meet me. Then a call goes up and birds come from all over. Being near the water, we have many swallows and houses are built for them all over the place. When the little ones are about to leave, excitement reigns high and they have visitors all day long.

It is marvelous to watch all of them and we get hours of enjoyment with them, much to the detriment of our garden I'm afraid. 